\title{
The Host Stomatal Density Determines Resistance to Septoria gentianae in Japanese Gentian
}

\author{
Chika Tateda, ${ }^{1}$ Kazue Obara, ${ }^{1}$ Yoshiko Abe, ${ }^{1}$ Reiko Sekine, ${ }^{2}$ Syuuichi Nekoduka, ${ }^{3}$ Takashi Hikage,${ }^{4}$ \\ Masahiro Nishihara, ${ }^{1}$ Ken-Taro Sekine, ${ }^{2}$ and Koki Fujisaki ${ }^{1, \dagger}$ \\ ${ }^{1}$ Iwate Biotechnology Research Center, 22-174-4 Narita, Kitakami, Iwate 024-0003, Japan; ${ }^{2}$ Iwate Plant Protection Office, 20-1 \\ Narita, Kitakami, Iwate 024-0003, Japan; ${ }^{3}$ University of the Ryukyus, Faculty of Agriculture, Nakagami, Okinawa 903-0213, \\ Japan; ${ }^{4}$ Hachimantai City Floricultural Research and Development Center, Kamasuda 70, Hachimantai, Iwate 028-7533, Japan
}

Accepted 4 October 2018.

\begin{abstract}
Plant stomata represent the main battlefield for host plants and the pathogens that enter plant tissues via stomata. Septoria spp., a group of ascomycete fungi, use host plant stomata for invasion and cause serious damage to agricultural plants. There is no evidence, however, showing the involvement of stomata in defense systems against Septoria infection. In this study, we isolated Septoria gentianae 20-35 ( $\mathrm{Sg} 20-35)$ from Gentiana triflora showing gentian leaf blight disease symptoms in the field. Establishment of an infection system using gentian plants cultured in vitro enabled us to observe the $S g 20-35$ infection process and estimate its virulence in several gentian cultivars or lines. $S g$ 20-35 also entered gentian tissues via stomata and showed increased virulence in $G$. triflora compared with G. scabra and their interspecific hybrid. Notably, the susceptibility of gentian cultivars to $S g 20-35$ was associated with their stomatal density on the adaxial but not abaxial leaf surface. Treatment of EPIDERMAL PATTERNING FACTOR-LIKE 9 (EPFL9/STOMAGEN) peptides, a small secreted peptide controlling stomatal density in Arabidopsis thaliana, increased stomatal density on the adaxial side of gentian leaves as well. Consequently, treated plants showed enhanced susceptibility to $\mathrm{Sg20-35}$. These results indicate that stomatal density on the adaxial leaf surface is one of the major factors determining the susceptibility of gentian cultivars to $S$. gentianae and suggest that stomatal density control may represent an effective strategy to confer Septoria resistance.
\end{abstract}

Plants have multiple defense systems, including preformed resistance and induced resistance against pathogen attacks. The presence of a wax layer, cell wall thickness, and accumulation of antimicrobial compounds in the absence of pathogens are known as preformed resistance (Moerschbacher and Mendgen 2000). Conversely, defense responses such as pathogen-associated molecular pattern (PAMP)-triggered immunity (PTI) are known as an induced resistance (Jones and Dangl 2006). In the case of PTI, pattern recognition receptors such as FLAGELLIN SENSING2 (FLS2), EF-Tu receptor (EFR), and CHITIN ELICITOR RECEPTOR

${ }^{\dagger}$ Corresponding author: K. Fujisaki; E-mail: k-fujisaki@ibrc.or.jp

Funding: This study was financially supported by Iwate Prefecture, Japan, Japan Society of the Promotion of Science, KAKENHI (grant number $18 \mathrm{~K} 05660$ ).

The author(s) declare no conflict of interest.

(C) 2019 The American Phytopathological Society
KINASE/LYSM DOMAIN RECEPTOR-LIKE KINASE1 (CERK1) recognize PAMPs (Chinchilla et al. 2007; GómezGómez and Boller 2000; Miya et al. 2007; Petutschnig et al. 2010; Willmann et al. 2011; Zipfel et al. 2006); these receptors then activate downstream signaling regulated by several cellular components such as mitogen-activated protein kinases (MPKs) (Macho and Zipfel 2014; Schwessinger et al. 2011). Resulting defense responses such as papilla formation, lignification of the cell wall, and accumulation of phytoalexin and pathogenesis-related proteins block pathogen infection (Ahuja et al. 2012; Miedes et al. 2014; Stintzi et al. 1993; Underwood. 2012).

A number of bacterial, fungal, and oomycete pathogens utilize host stomata to enter plant tissues (Giraldo and Valent 2013; Melotto et al. 2006; Schoina and Govers 2015). Thus far, rapid stomatal closure has been observed during pathogen infections; this is known to be a defense response to guard gates against pathogen invasions (Arnaud and Hwang 2015; Melotto et al. 2006). Previous reports demonstrated possible relationships between PTI and stomatal immunity. PAMPs trigger stomatal closure in host plants (Liu et al. 2009; Su et al. 2017) and an MPK cascade regulates the stomatal closure (Gudesblat et al. 2009; Su et al. 2017). In addition to the regulation of stomatal closure or aperture, stomatal density can differ among host plants. Mutations in some PTI-related genes (serk1-1/serk2-1/bakl-5, mpk3/mpk6, and $m k k 4 m k k 5$ ) increase stomatal density (Meng et al. 2015; Su et al. 2017; Wang et al. 2007). Based on these reports, plant stomata are regarded as one of the main battlefields during pathogen infection.

In Arabidopsis thaliana, stomatal density is controlled by small secreted peptide from EPIDERMAL PATTERNING FACTOR/EPF-like (EPF/EPFL) proteins and their receptors, including ERECTA family leucine-rich repeat receptor-like kinase (ER), ER-LIKE 1, and TOO MANY MOUTHS (Han and Torii 2016; Zoulias et al. 2018).

Arabidopsis er mutants show high stomatal density and enhanced susceptibility to bacterial, fungal, and oomycete pathogens (Jordá et al. 2016). EPF/EPFL genes encode cysteinerich proteins that contain signal peptides and EPF/EPFL active peptide regions (Katsir et al. 2011; Marshall et al. 2011). EPF1 and EPF2 negatively regulate the development of stomata while EPFL9/STOMAGEN positively regulates stomatal density (Hara et al. 2007, 2009; Hunt and Gray 2009; Hunt et al. 2010; Kondo et al. 2010; Sugano et al. 2010). Treatment with active EPFL9 peptide increased stomatal density (Kondo et al. 2010; Sugano et al. 2010). These EPF/EPFL genes are found in both monocotyledonous and dicotyledonous plants (Takata et al. 2013), suggesting the presence of a conserved regulatory mechanism of plant stomatal density.

Gentian (Gentiana L.) is an important ornamental flower in Japan. Gentiana triflora Pall. var. japonica (Kusn.) Hara, 
G. triflora var. japonica f. montana (Hara) Toyokuni, G. scabra Bunge var. buergeri (Miq). Maxim.), and their interspecific hybrids are mainly used as cultivars or lines in Japan (Nishihara et al. 2018; Yoshiike 1992). Several gentian fungal diseases, including gentian leaf blight, gentian brown leaf spot, and gentian sclerotial flower blight, have been reported (Nekoduka et al. 2013; Ohno et al. 1996; Saito and Kaji 2006). Septoria gentianae, an ascomycete fungal pathogen of gentian, causes the gentian leaf blight disease that typically shows necrotic leaves with black spots (pycnidia formation of Septoria) on the adaxial side of the leaf surface (Ohno et al. 1996; Saccardo 1884). Although some environmental conditions (e.g., temperature and humidity) influence the susceptibility of gentians to S. gentianae (Ohno et al. 1996), the detailed mechanism controlling $S$. gentianae infection is yet to be reported.

Zymoseptoria tritici (Mycosphaerella graminicola or S. tritici), which causes Septoria tritici blotch (speckled leaf blotch) disease in wheat, is a well-studied Septoria sp. (Dean et al. 2012; Fones and Gurr 2015; Steinberg 2015; Van Ginkel and Rajaram 1993). $Z$. tritici grows on leaf surfaces, forms appressorium-like structures on host stomata, and enters leaf tissues via the stomatal cavity. Fungal hyphae colonize the intercellular space and then pycnidia are formed in the stomatal cavity (Cohen and Eyal 1993; Duncan and Howard 2000; Hilu and Bever 1957; Kema et al. 1996; Shipton et al. 1971;Steinberg 2015). In addition to Z. tritici, other Septoria spp. that cause serious damage to agricultural plants worldwide (Niyo et al. 1986; Stevenson 1991) utilize stomata for their infection (Kema et al. 1996; Martin-Hernandez et al. 2000; Niyo et al. 1986), suggesting the importance of host stomata in the life cycle of Septoria spp.

In this study, $S$. gentianae 20-35 ( $S g 20-35)$ was isolated from Japanese gentian showing leaf blight diseases in Iwate Prefecture, Japan. A pathosystem using $S g 20-35$ and gentian plants cultured in vitro was established and used to estimate the susceptibility of several gentian cultivars or lines to S. gentianae. We found that the susceptibility of gentian cultivars to $S$. gentianae associated strongly with the stomatal density on the adaxial side of gentian leaves and that increasing the stomatal density with peptide treatment reduced disease resistance. The importance of stomatal density in the susceptibility of gentians to $S$. gentianae was analyzed.

\section{RESULTS}

\section{Isolation of $S$. gentianae from Japanese gentian cultivated in the field.}

The leaf blight fungus (20-35) was isolated from a cultivar of $G$. triflora showing leaf blight diseases in Iwate Prefecture, Japan (Fig. 1A). The morphology of conidia of the isolate resembled those of Septoria spp. (Fig. 1B). S. gentianae has previously been reported as the pathogen of leaf blight diseases of Japanese gentians (Ohno et al. 1996). Supporting this report, genomic DNA sequences of four loci, including internal transcribed spacer (ITS), calmodulin (Cal), $\beta$-tubulin ( $\beta$ Tub), and translation elongation factor $1-\alpha(\mathrm{EF})$, demonstrated $99 \%$ identity to all four sequences of a previously isolated leaf blight fungus, S. gentianae strain CBS128633 (Table 1) (Verkley et al. 2013), suggesting that $S$. gentianae strain CBS128633 is the most closely related fungus to 20-35 of the six Septoria spp. for which genomic sequence information is available. Therefore, we designated our fungus $S$. gentianae isolate 20-35.

\section{The leaf blight disease symptoms appear} on the leaf surface of gentian in vitro.

Most gentian cultivars or lines are derived from G. triflora, G. scabra, or an interspecific hybrid (hybrid) in Iwate, Japan.
To check the pathogenicity of $S g 20-35$, we established a pathosystem for $S$. gentianae using gentian plants cultured in vitro. $S g$ 20-35 spores were sprayed on the adaxial leaf surface of three cultivars or lines-Yahaba $(G$. triflora), Alta (G. scabra), and To (G. scabra)—and inoculated plants were incubated under experimental conditions (discussed below). After 21 days postinoculation (dpi), Yahaba successfully showed typical leaf blight symptoms, with black spots (Fig. 1C top panel) that are similar to those observed in natural field
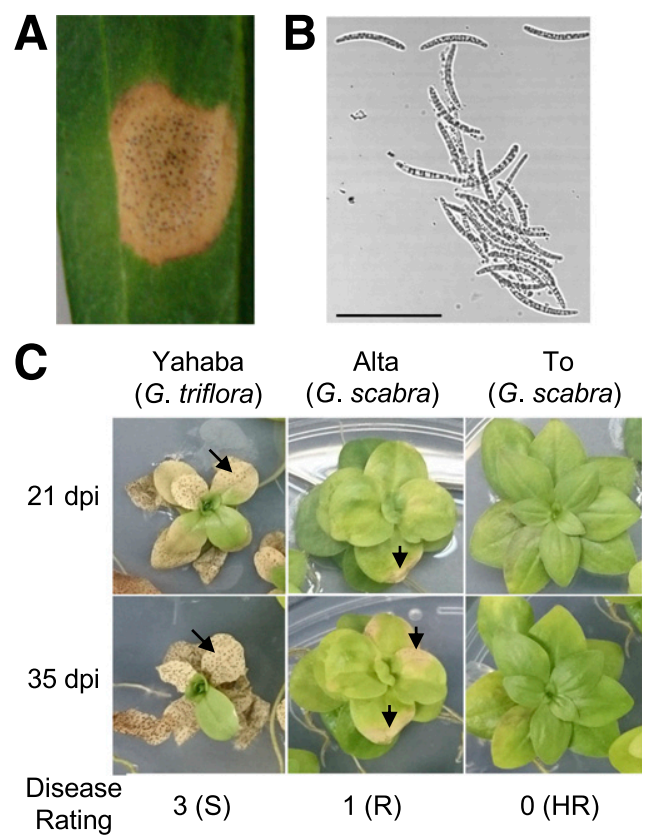

Fig. 1. Septoria gentianae isolate 20-35 ( $\mathrm{Sg} 20-35)$ shows different pathogenicity with different gentian cultivars and lines. A, Gentiana triflora showing leaf blight disease symptoms in natural field conditions. B, Conidia of $S g$ 20-35 on potato dextrose agar medium. Scale bar: $20 \mu \mathrm{m}$. The image was obtained by an optical microscope. C, Visible symptoms and disease rating of three gentian cultivars or lines (Yahaba, Alta, and To). Plants were photographed at 21 days postinoculation (dpi) (top panel) or 35 dpi (bottom panel). Arrow indicates typical disease symptoms associated with $S g 20-35$. S = susceptible, $\mathrm{R}=$ resistant, and HR = hyper-resistant.

Table 1. Sequence identity of four genomic sequences-internal transcribed spacer (ITS), calmodulin (Cal), $\beta$-tubulin ( $\beta$ Tub), and translation elongation factor 1- $\alpha$ (EF)—of Septoria gentianae isolate 20-35 (Sg20-35) to those of Septoria spp.

\begin{tabular}{|c|c|c|c|c|}
\hline \multirow[b]{2}{*}{ Septoria spp. ${ }^{\text {a }}$} & \multicolumn{4}{|c|}{$S g 20-35(\%)$} \\
\hline & ITS & Cal & $\beta$ Tub & EF \\
\hline Septoria gentianae strain CBS 128633 & 99 & 99 & 99 & 99 \\
\hline S. microspora strain TCM-9 & 99 & N.F. ${ }^{b}$ & N.F. & N.F \\
\hline S. oenanthicola CBS 128649 & 98 & 97 & 98 & 95 \\
\hline S. aegopodina CBS 123740 & 98 & 97 & 96 & 95 \\
\hline S. digitalis strain CBS 328.67 & 98 & 96 & 83 & 79 \\
\hline S. lycopersici strain CBS 128654 & 98 & 95 & 83 & 79 \\
\hline
\end{tabular}

${ }^{a}$ Accession numbers are as follows. Sg20-35: ITS = LC380031, Cal = LC380032, $\beta$ Tub = LC380033, EF = LC380034; S. gentianae strain CBS 128633: ITS = KF251426.1, Cal = KF254078.1, $\beta$ Tub = KF252898.1, $\mathrm{EF}=\mathrm{KF} 253374.1 ;$ S. microspora strain TCM-9: ITS = KC874679.1; S. oenanthicola $\mathrm{CBS}$ 128649: ITS = KF251234.1, Cal = KF254137.1, $\beta \mathrm{Tub}=\mathrm{KF} 252954.1, \mathrm{EF}=\mathrm{KF} 253433.1 ;$ S. aegopodina $\mathrm{CBS} 123740$ : $\mathrm{ITS}=\mathrm{KF} 251334.1, \mathrm{Cal}=\mathrm{KF} 253986.1, \beta \mathrm{Tub}=\mathrm{KF} 252806.1, \mathrm{EF}=\mathrm{KF} 253281.1$; $S$. digitalis strain CBS 328.67: ITS = KF251401.1, Cal = KF254053.1, $\beta \mathrm{Tub}=\mathrm{KF} 252872.1, \mathrm{EF}=\mathrm{KF} 253348.1$; and $S$. lycopersici strain CBS 128654: ITS $=$ JX901797.1, Cal = KF254114.1, $\beta$ Tub $=$ JX902288.1, $\mathrm{EF}=\mathrm{KF} 253410.1$

b N.F. indicates that information was not in the National Center for Biotechnology Information database. 
conditions (Fig. 1A). Compared with Yahaba, Alta showed mild symptoms. Black spots on Alta leaves were not observed at $21 \mathrm{dpi}$ and appeared at $35 \mathrm{dpi}$ (Fig. 1C). On the other hand, To did not show any visible symptoms, even at 35 dpi (Fig. 1C, bottom panel), indicating that these three gentians have different susceptibility to $S g 20-35$.

\section{Gentian susceptibility to $S$. gentianae is primarily determined in a gentian species-dependent manner.}

Because three cultivars or lines (Yahaba, Alta, and To) showed different susceptibility, we further investigated the susceptibility of other expanded cultivars or lines from G. triflora, G. scabra, and their hybrids. (Table 2). Based on the results shown in Figure 1, disease rating was scored as follows: disease rating $3=$ more than $70 \%$ of the leaf area showed disease symptoms (i.e., Yahaba; susceptible), disease rating $1=$ less than $30 \%$ of the leaf area showed disease symptoms (i.e., Alta; resistant), and disease rating $0=$ no visible symptom (i.e., To; hyper-resistant). As far as we tested, all four cultivars of G. triflora showed disease rating 3 (susceptible), whereas all three hybrid cultivars or lines and four of five G. scabra cultivars or lines showed disease rating 1 (resistant) (Table 2). Uniquely, only the To line (G. scabra) showed disease rating 0 (hyper-resistant) (Table 2). Then, we quantified the susceptible levels of gentian cultivars or lines by counting the number of pycnidia on inoculated leaf surface. In $20 \mathrm{~mm}^{2}$ of leaf area, two cultivars of $G$. triflora showed a large number of pycnidia (Yahaba, $33.42 \pm 5.89$ and Maciry, $35.23 \pm 7.19$ ). Compared with them, two G. scabra cultivars or lines (Alta, $0.65 \pm 0.79$ and To, $0 \pm 0$ ) and two hybrid cultivars (Polano White [PW], $6.35 \pm 4.84$ and Albireo, $0.96 \pm 1.06)$ showed fewer pycnidia. Overall, these data demonstrate an association between gentian species and their susceptibility to $S$. gentianae and, therefore, suggest the presence of gentian species-dependent resistance against $S$. gentianae.

\section{Fungal development of $S$. gentianae before invasion} does not differ between gentian species.

To determine the mechanism of gentian species-dependent resistance against $S$. gentianae, we observed fungal growth on gentian leaves. On the leaves of a susceptible line (Yahaba), conidia of $S$. gentianae germinated at $1 \mathrm{dpi}$ and hyphae started entering host leaves via host stomata at 2 dpi (Fig. 2A). At 3 dpi, appressorium-like structures, which were previously described in M. graminicola ( $Z$. tritici) infection (Siah et al. 2010), appeared at stomata (Fig. 2A). At 14 dpi, the cells around stomata were stained by trypan blue (Fig. 2A), which may be derived from fungal hyphae and dying host cells. These data indicate that $S$. gentianae, like other Septoria spp., enters host tissues via stomata. Next, we examined fungal growth on the leaves of resistant cultivars Alta and PW (Table 2). However, fungal invasive manner, development of infection hyphae, and formation of appressorium-like structures were not qualitatively different between both resistant cultivars (Alta and PW) and susceptible line Yahaba at 3dpi (Fig. 2B).

\section{The host stomatal density associates with susceptibility of gentian cultivars to $S$. gentianae.}

S. gentianae enters host tissues via stomata on the adaxial side of gentian leaves (Fig. 2). Therefore, we focused on the stomatal density of three cultivars or lines: Yahaba (G. triflora), PW (hybrid), and Alta (G. scabra). Interestingly, PW and Alta had lower stomatal density than Yahaba on the adaxial leaf surface (Fig. 3A, left panel), whereas all three cultivars had a similar stomatal density on the abaxial leaf surface (Fig. 3A, right panel). This suggests that stomatal density on the adaxial leaf surface might be dependent on gentian species. Next, we examined the stomatal density of other G. triflora, G. scabra, and hybrid gentians. Compared with most of the cultivars or lines of G. scabra and the hybrids, all four G. triflora cultivars or lines (Yahaba, Maciry, SpB, and Go1259) had 2 to 3 times higher stomatal density on the adaxial leaf surface (Fig. 3B). Uniquely, the To line, which showed hyper-resistance against $S$. gentianae, had an extremely low number of stomata (zero or a couple of stomata per leaf) on the adaxial leaf surface (Fig. 3B, left panel). In contrast to the differing stomatal density on the adaxial side of different gentians, there was no significant difference in stomatal density on the abaxial side among different gentians (Fig. 3C). Notably, the stomatal density of the adaxial but not abaxial leaf surface was associated with the susceptibility of gentians to $S$. gentianae (Table 2), suggesting that gentian susceptibility to $S$. gentianae is determined by stomatal density on the adaxial leaf surface, the main infection site in this assay and natural fields (Ohno et al. 1996; Saccardo 1884). Supporting this hypothesis, spot inoculation of injured leaves of the hyper-resistant To line led to necrotic symptoms (Fig. 4). Consistent with this result, severe necrotic symptoms were observed on inoculated leaves of a resistant cultivar (PW) after punch inoculation but not spray inoculation. The level of symptom development was similar to that on Yahaba (Fig. 4B). This suggests that $S g 20-35$ infection was blocked at the invasive step in To and PW, potentially indicating the importance of stomata in the resistance of To and PW. On the other hand, Alta showed resistance in both spray- and punch-inoculation assays (Fig. 4C), suggesting resistance to S. gentianae after invasion in Alta. Therefore, these data further indicated that

Table 2. Disease rating and stomatal density of several gentian cultivars and lines

\begin{tabular}{|c|c|c|c|c|}
\hline Cultivar or line & Gentian species & Disease rating $^{\mathbf{a}}$ & Stomatal density on adaxial side ${ }^{b}$ & No. of pycnidia in $20 \mathrm{~mm}^{2}$ of leaf area \\
\hline Yahaba & Gentiana triflora & $3(\mathrm{~S})$ & High & $33.42 \pm 5.89$ \\
\hline Maciry & G. triflora & $3(\mathrm{~S})$ & High & $35.23 \pm 7.19$ \\
\hline $\mathrm{SpB}$ & G. triflora & $3(\mathrm{~S})$ & High & N.A. ${ }^{c}$ \\
\hline Go1259 & G. triflora & $3(\mathrm{~S})$ & High & N.A. \\
\hline Albireo & G. triflora $\times$ G. scabra & $1(\mathrm{R})$ & Low & $0.96 \pm 06$ \\
\hline Polano white & G. triflora $\times$ G. scabra & $1(\mathrm{R})$ & Low & $6.35 \pm 4.84$ \\
\hline Go $1259 \times$ Go 860 & G. triflora $\times$ G. scabra & $1(\mathrm{R})$ & Low & N.A. \\
\hline Alta & G. scabra & $1(\mathrm{R})$ & Low & $0.65 \pm 0.79$ \\
\hline To & G. scabra & 0 (HR) & Extremely low & $0 \pm 0$ \\
\hline Aokorin & G. scabra & $1(\mathrm{R})$ & Low & N.A. \\
\hline Go860 & G. scabra & $1(\mathrm{R})$ & Low & N.A. \\
\hline
\end{tabular}

${ }^{a}$ Rating 3 (S) indicates $>70 \%$ of area showed disease symptoms (susceptible); 1 (R) indicates $<30 \%$ of area showed disease symptoms (resistance), and 0 (HR) indicates no visible disease symptoms (hyper-resistance).

${ }^{\mathrm{b}}$ High = levels of stomatal density similar to Yahaba, Low = levels of stomatal density similar to Polano White (PW), and Extremely low = no or only a few stomata were found on each leaf.

${ }^{c}$ N.A. $=$ not assayed. 
gentians potentially have multiple resistance mechanisms to S. gentianae.

\section{The regulation of stomatal density with EPF/EPFL peptides affects susceptibility to $S$. gentianae.}

Because stomatal density may be a major factor determining the susceptibility of gentians to $S$. gentianae, we attempted to regulate the stomatal density and evaluate disease resistance in gentians cultured in vitro. Treatment with STOMAGEN (EPFL9) active peptide has previously been shown to increase the stomatal density of Arabidopsis leaves (Kondo et al. 2010; Sugano et al. 2010). Therefore, we tested the effects of Arabidopsis STOMAGEN peptide treatment on the stomatal density of gentians. After treatment with STOMAGEN, resistant hybrid cultivar PW had increased stomatal density compared with control peptide-treated PW (Fig. 5B). Similar results were observed in the treated To line (Fig. 5C), which has an extremely low level of stomatal density on the adaxial leaf surface, indicating that STOMAGEN functions to increase stomatal density in gentians as well as in A. thaliana. Next, we examined the susceptibility of STOMAGEN-treated gentians to $S g$ 20-35. After spray inoculation with $S g 20-35$, STOMAGENtreated PW plants showed more severe disease symptoms (Fig. 5D). Even in the hyper-resistant To line, STOMAGEN treatment allowed $S g 20-35$ to induce typical leaf blight disease symptoms (necrotic symptoms with black spots) (Fig. 5E). Therefore, we concluded that stomatal density is one of the most critical factors determining the susceptibility of gentians to $S$. gentianae.

\section{DISCUSSION}

In this study, we found that two gentian species, G. triflora and G. scabra, had different levels of stomatal density on the adaxial leaf surface and that the susceptibility to $S$. gentianae of several gentian cultivars or lines derived from these two gentian species associated strongly with stomatal density. Furthermore, STOMAGEN peptide treatment of gentian plants led to increased stomatal density and enhanced susceptibility to S. gentianae. These data highlighted the importance of stomatal density for Septoria resistance in gentian plants at the species level.

To date, a number of reports have focused on stomata in terms of plant immunity. Stomatal closure, which is regarded as a typical defense response to block pathogen invasion, is closely related to the PTI pathway (Gudesblat et al. 2009; Liu et al. 2009; Su et al. 2017). Conversely, our findings indicate that stomatal density, not the regulation of stomatal closure or aperture, is associated with pathogen defense. Previous reports indicated that some artificially generated Arabidopsis mutants of PTI-related genes showed increased stomatal density and enhanced susceptibility to pathogens such as serk1-1/serk2-1/ bak1-5, er105/bak1-5, mpk3/mpk6, and mkk4 mkk5 (Jordá et al. 2016; Meng et al. 2015; Su et al. 2017; Wang et al. 2007). Moreover, er (EPF/EPFL receptor) mutants also showed high stomatal density and enhanced susceptibility (Jordá et al. 2016), suggesting that stomatal density has significant effects on plant susceptibility to pathogens.

Our results indicated the presence of stomatal densitydependent resistance in naturally occurring gentian species. Because the variety of stomatal density among gentian cultivars was observed prior to pathogen challenge, Septoria resistance described in this study is regarded as preformed resistance. Although our results suggest that gentian susceptibility to S. gentianae is primarily determined by stomatal density, we do not exclude the possibility that other resistance mechanisms such as PTI also determine the different susceptibility of gentian cultivars to $S$. gentianae. In fact, Alta showed limited disease symptoms even after punch inoculations of $S g 20-35$ (Fig. 4). This is in contrast to the Yahaba, PW, and To lines or cultivars and implies another resistance mechanism to restrict fungal growth after invasion in Alta. Additionally, a series of
A

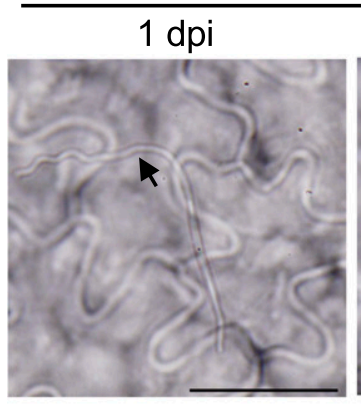

\section{B Yahaba}

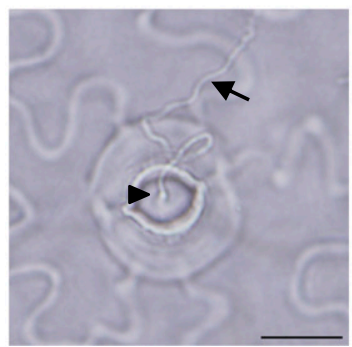

Yahaba
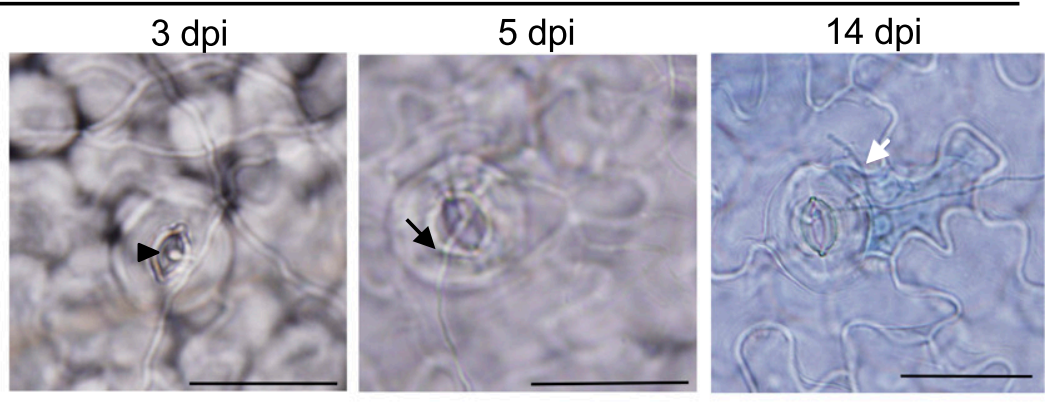

Alta
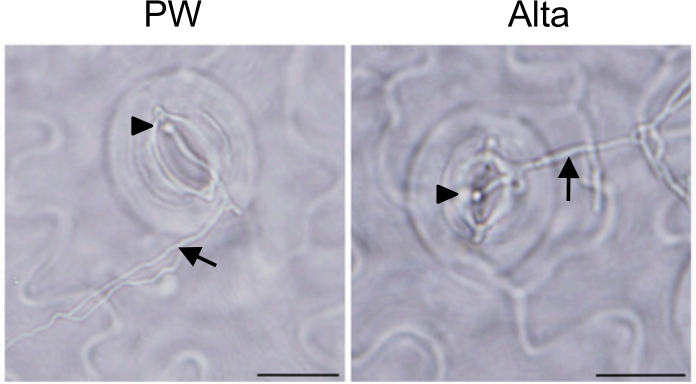

Fig. 2. Septoria gentianae isolate 20-35 ( $\mathrm{Sg} 20-35)$ enters gentian tissues via host stomata. A, Leaf materials were collected at 1, 2, 3, 5, and 14 days postinoculation (dpi) to obtain images with an optical microscope. At $14 \mathrm{dpi}, S g 20-35$ and gentian cells were stained with trypan blue. Scale bar: $50 \mu \mathrm{m}$. B, Formation of Sg20-35 appressorium-like structures was similar on leaf surfaces of both susceptible (Yahaba) and resistant (PW and Alta) cultivars. Leaf materials were collected at 3 dpi to obtain images with an optical microscope. Black arrows and arrowheads indicate infection hyphae and appressorium-like structures, respectively. Scale bar: $20 \mu \mathrm{m}$. 
S. gentianae inoculation tests on the To line further suggested a crucial role of stomata in the development of characteristic symptoms of gentian leaf blight disease (black spots) (Fig. 1A). The To line developed no or only a small number of black spots even when necrosis was spread to entire leaves after punch inoculation (Fig. 4). Considering the life cycle of Z. tritici in wheat (Fones et al. 2015; Steinberg 2015), black spots are derived from pycnidia formed on stomata in which descendant conidia are contained. Nontreated and STOMAGEN-treated To lines had no or only a small number of stomata on the adaxial leaf surface; thus, $S$. gentianae may have been unable to form many pycnidia (as black spots) on To leaves. Therefore, the absence or reduction of stomata numbers should have significant effects on the life cycle of $S$. gentianae in gentian, even if it can enter host tissues via wound sites.

The importance of stomatal density in $S$. gentianae resistance may facilitate the development of a novel strategy to control plant diseases. In natural field conditions, leaf blight disease symptoms caused by $S$. gentianae were usually observed on the adaxial side of gentian leaves (Ohno et al. 1996; Saccardo 1884). The To line (G. scabra) has no or only a few stomata on the adaxial side of its leaves, suggesting that the stomata on adaxial leaf surfaces should not be essential for gentian growth. Therefore, control of stomatal density on adaxial leaf surfaces could be an effective tool to confer Septoria resistance without growth defects. Stomatal density varies among gentian cultivars; therefore, a cross-breeding or genetic engineering approach may be used to regulate stomatal density and produce plants resistant to leaf blight disease. Use of interspecific hybrids is not limited to gentian cultivars. In the case of tomato, which is a host plant of related fungal pathogen S. lycopersici, different species of tomato (e.g., Solanum lycopersicum, $S$. pennelli, $S$. peruvianum, $S$. habrochaites, and $S$. pimpinellifolium) are used as parents for breeding. Interestingly, $S$. lycopersicum and $S$. pennelli have different stomatal densities on their adaxial leaf surfaces (Heichel and Anagnostakis 1978), suggesting that a genetic approach to control stomatal density may be applicable to other plant species as well as gentians.

In this study, treatment with Arabidopsis STOMAGEN peptide could increase stomatal density in gentians, suggesting that STOMAGEN function is basically conserved in several plant species. Consistent with this result, EPF/EPFL genes, including STOMAGEN (EPFL9), are found in both eudicot and monocot plants (Takata et al. 2013). In A. thaliana, STOMAGEN
A Adaxial

Abaxial
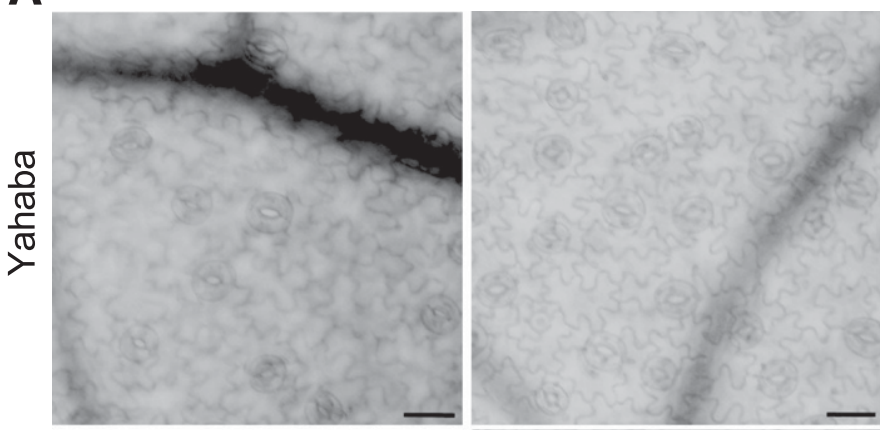

2
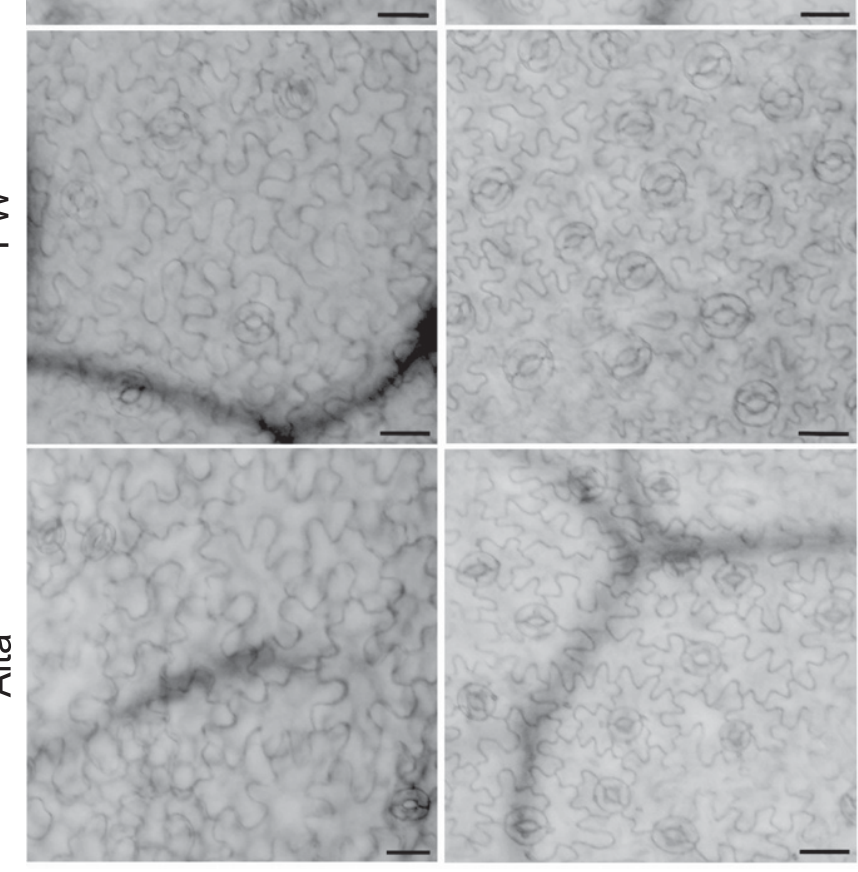

B
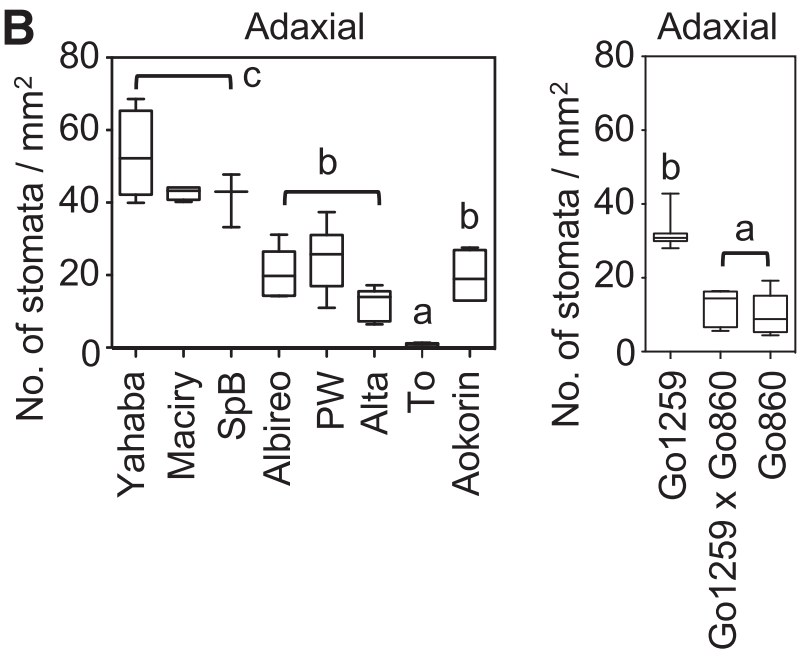

C

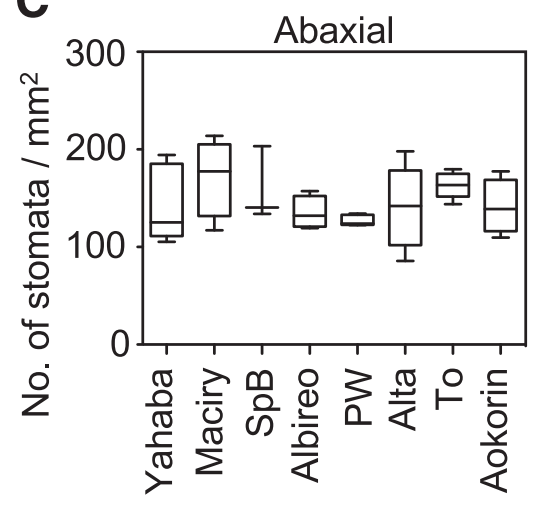

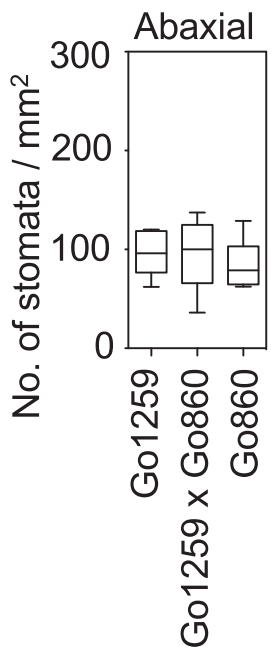

Fig. 3. Gentian cultivars and lines have different stomatal densities on the adaxial side leaf surface. A, Stomatal patterning of adaxial (left panel) or abaxial (right panel) surfaces of Yahaba, PW, and Alta leaves. Images were obtained with an optical microscope. Scale bar: $40 \mu$ m. Stomatal density of B, adaxial and C, abaxial leaf surfaces of several gentian cultivars or lines. Images were obtained with an optical microscope and the number of stomata was counted. Mean values were calculated from the number of stomata on each of six plants. Error bar indicates standard deviation. Whiskers indicate minimum to maximum. Letters ( $\mathrm{a}, \mathrm{b}$, or c) above the error bars indicate the groups from the Newman-Keuls Multiple Comparison Test. Go1259, Go860, and their hybrid plants (B and C) were prepared from seedlings while others were prepared from shoot tips (discussed below); their stomatal density was estimated in independent experiments. Data are separately indicated in the right (Go1259, Go860, and their hybrid) and left (others) panels. 
is known as a positive regulator of stomatal development, while other $E P F / E P F L$ genes such as EPF1, EPF2, EPFLA, EPFL5, and EPFL6 negatively regulate stomatal development (Abrash and Bergmann 2010; Hara et al. 2007, 2009; Hunt and Gray 2009; Hunt et al. 2010; Kondo et al. 2010; Niwa et al. 2013; Sugano et al. 2010). Although there is no information available on these genes in gentians, these data suggest that exogenous application of EPF/EPFL peptides or other novel chemical compounds that negatively regulate stomatal development can also be used to control Septoria diseases. In general, not only Septoria spp. but also several bacterial, fungal, and oomycete pathogens utilize stomata to enter host tissues. Research into the broader applications of plant disease control by the regulation of stomatal density must be performed in the future.

\section{MATERIALS AND METHODS}

\section{Isolation and identification of Septoria gentianae.}

Diseased leaves of gentian plants infected by leaf blight were collected and mixed with distilled water (DW). The spore suspension was incubated on potato dextrose agar (PDA; Nissui Pharmaceutical Co., Ltd.) at $15^{\circ} \mathrm{C}$. Fungal colonies were isolated and recultured on PDA at $15^{\circ} \mathrm{C}$ for 21 days. To isolate genomic DNA, a piece of PDA with mycelia was transferred into V8 juice broth (Miller 1955), with some modification $\left(2.5 \% \mathrm{~V} 8\right.$ juice and $0.9 \mathrm{~g}$ of $\left.\mathrm{CaCO}_{3}\right)$ and incubated at $15^{\circ} \mathrm{C}$ for 2 days with shaking at $110 \mathrm{rpm}$. Cultures were filtered through miracloth (Merck) and centrifuged at 5,000 $\times g$ for $5 \mathrm{~min}$. Fungal genomic DNA was isolated using the thermolysis method, as described previously (Zhang et al. 2010), with some modification. The pellet was suspended with lysis solution (50 mM Tris- $\mathrm{HCl}$ [pH 8.0], $1 \mathrm{mM}$ EDTA, and 5\% tlycerol) and incubated at $85^{\circ} \mathrm{C}$ for $30 \mathrm{~min}$ before the suspended solution was centrifuged at $11,000 \times g$ for $5 \mathrm{~min}$, and the resulting supernatant was used as the genomic DNA solution. To identify fungal species, genomic polymerase chain reaction (PCR) using the following primer sets was performed: for ITS, ITS-ITS5

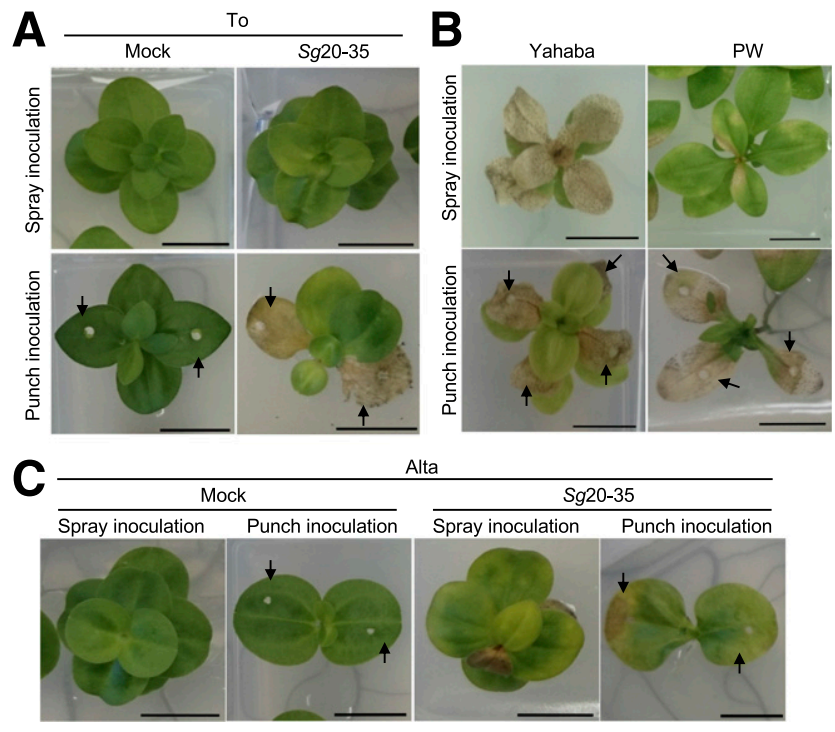

Fig. 4. Different levels of symptoms appeared on the leaf surface of gentian cultivars after punch inoculation. A, Symptoms appeared on the leaf surface of the To line after spray and punch inoculation of Septoria gentianae isolate 20-35 ( $S g 20-35)$. B, Symptoms appeared on leaf surface of Yahaba and PW after spray and punch inoculation of Sg20-35. C, Symptoms appeared on leaf surface of Alta after spray and punch inoculation of $\mathrm{Sg} 2 \mathrm{O}$ 35. Scale Bar: $1 \mathrm{~cm}$. After punch inoculation, plants were photographed after removal of newly grown uninoculated upper leaves at 35 days postinoculation. Arrow indicates inoculated leaves in punch-inoculation assay.
(5'-GGAAGTAAAAGTCGTAACAAGG-3') and ITS-ITS4 $\left(5^{\prime}\right.$-TCCTCCGCTTATTGATATGC-3') (White et al. 1990); for $\beta$ Tub, $\beta$ Tub-T1 (5'-AACATGCGTGAGATTGTAAGT-3') (O'Donnell and Cigelnik 1997) and $\beta$ Tub-R (5'-GCRCGNG GVACRTACTTGTT-3') (Stukenbrock et al. 2012); for Cal, Cal235F (5'-TTCAAGGAGGCCTTCTCCCTCTT-3') (Quaedvlieg et al. 2012) and Cal-2Rd (5'-TGRTCNGCCTCDCGGATC ATCTC-3') (Quaedvlieg et al. 2012); and for EF, EF1-728F (5'CATCGAGAAGTTCGAGAAGG-3') (Carbone and Kohn 1999) and EF-2 (5'-GGARGTACCAGTSATCATGTT-3') (O'Donnell et al. 1998). PCR was performed with Ex Taq (Takara), and resulting PCR products were cloned into the TOPOTA cloning vector (Thermo Fisher Scientific). Nucleotide sequences were determined using the M13 forward (5'-GTAAAACGACGGCC AG-3') or M13 reverse (5'-CAGGAAACAGCTATGAC-3') primers.
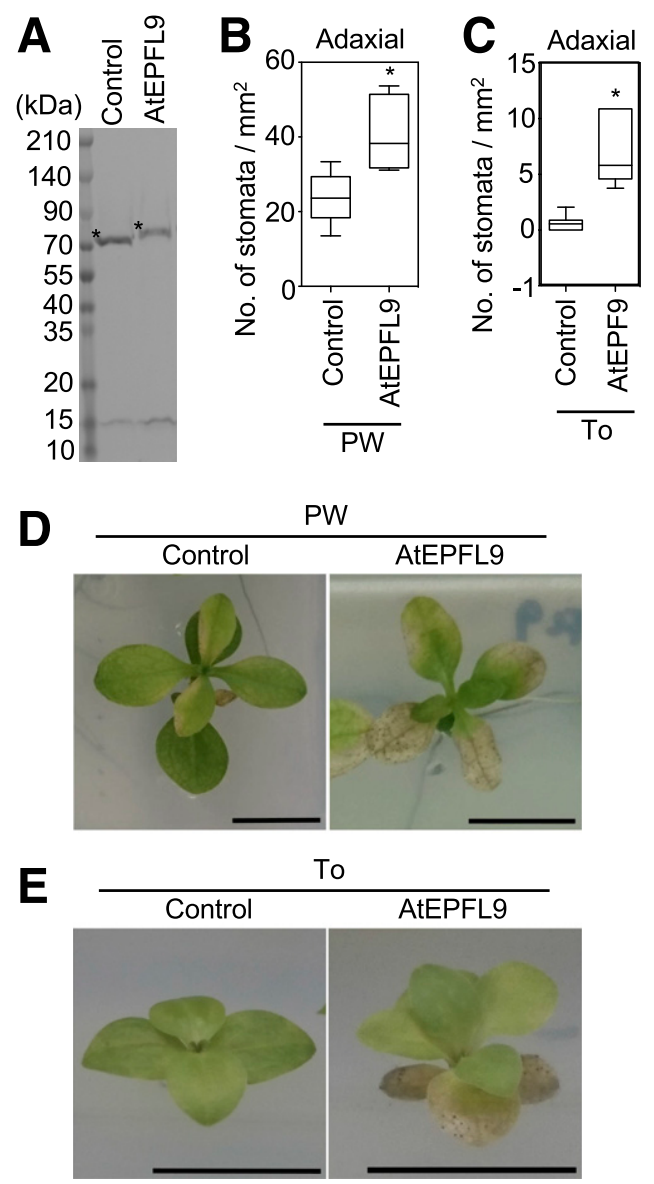

Fig. 5. Regulation of stomatal density and gentian disease susceptibility by STOMAGEN (EPFL9) active peptide. A, His-Tag/Trigger Factor (TF)fused STOMAGEN expressed in Escherichia coli was purified and analyzed by sodium dodecyl sulfate polyacrylamide gel electrophoresis and Coomassie Brilliant Blue staining. A recombinant protein consisting of only His-Tag/TF was used as a negative control. Asterisks indicate purified proteins. B, STOMAGEN-treated PW plants had increased stomatal density on the adaxial leaf surface compared with control plants. C, Stomata on the adaxial leaf surface of To plants after STOMAGEN treatment. For B and C, leaves were collected 30 days after recombinant peptide treatment at 2 $\mu \mathrm{g} / \mathrm{ml}$. Asterisks indicate significant differences $(P<0.01$; Student's $t$ test $)$. Three independent experiments were performed. D, Enhanced disease symptoms of STOMAGEN-treated PW plants at 35 days postinoculation (dpi). Plants were treated with STOMAGEN or control peptide for 30 to 40 days. Spray inoculation was used for $S g 20-35\left(5 \times 10^{5}\right.$ spores $\left./ \mathrm{ml}\right)$. Developing symptoms were photographed at 35 dpi. E, Disease symptoms on leaves of the To line. Plants were photographed at 28 dpi. 


\section{Plant materials and growth conditions.}

G. triflora, G. scabra, and their interspecific hybrid cultivars used in this study are listed in Table 2. These lines were obtained from Iwate Agricultural Research Center (IARC) and Hachimantai City Floricultural Research and Development Center (HFRDC). Gentian growth medium, consisting of onehalf Murashige and Skoog (1/2 MS) medium (Murashige and Skoog 1962), 3\% (wt/vol) sucrose, and $0.2 \%$ (wt/vol) gellan gum, was used to grow plants in vitro as described previously, with some modification (Hosokawa et al. 2000). Shoot tips were cultured at $22^{\circ} \mathrm{C}$ for 2 months under $16 \mathrm{~h}$ of light and $8 \mathrm{~h}$ of darkness for cultivars from IARC (Yahaba, Maciry, SpB, Albireo, PW, Alta, To, and Aokorin). Seed from HFRDC lines (Go1259, Go860, and Go1259 × Go860) were sterilized with 10 -fold diluted hypochlorous acid solution for $10 \mathrm{~min}$ and rinsed five times with sterile water. Seed were germinated on growth medium and 2-month-old seedlings were used for assays. A. thaliana (accession Columbia-0) was grown in $1 / 2 \mathrm{MS}$ media agar containing $1 \%(\mathrm{wt} / \mathrm{vol})$ sucrose under a photoperiod of $16 \mathrm{~h}$ of light and $8 \mathrm{~h}$ of darkness at $22^{\circ} \mathrm{C}$.

\section{Pathogenicity assay and disease rating.}

The 2-month-old plants were transferred to $1.2 \%$ agar 1 day before Septoria gentianae infection. For the pathogenicity assay, $S g$ 20-35 was incubated on PDA at $15^{\circ} \mathrm{C}$ for 21 weeks. For Figures $1 \mathrm{C}, 2$, and 4 and Table 2, the $S g 20-35$ spores in DW were sprayed on the adaxial side of the leaf surface of gentian plants at a concentration of $2 \times 10^{5}$ spores $/ \mathrm{ml}$. For Figure 4, press-injured spots ( $2 \mathrm{~mm}$ in diameter) were made on leaves by a pressing machine (Fujiwara) according to Kanzaki et al. (2002). $S g 20-35$ spores $(5 \mu \mathrm{l})$ at a concentration of $2 \times 10^{5}$ spores $/ \mathrm{ml}$ were dropped onto the injured spots on the leaves. Inoculated plants were incubated at $22^{\circ} \mathrm{C}$ for $24 \mathrm{~h}$ under dark conditions and then shifted to a photoperiod of $16 \mathrm{~h}$ of light and $8 \mathrm{~h}$ of darkness. The disease ratings in Figure 1 and Table 2 were scored at 35 days after $S g 20-35$ inoculation. For Figure 5, $\mathrm{Sg} 20-35$ in DW at a concentration of $5 \times 10^{5} \mathrm{spores} / \mathrm{ml}$ was sprayed onto the leaf surface of the PW or To line. For quantification analysis of $S$. gentianae infectivity, the number of pycnidia (black spots) on a $20-\mathrm{mm}^{2}$ leaf area was counted by using the Image J program. Averages and standard deviations of the number of pycnidia were calculated from six or more leaves of each gentian cultivar or line.

\section{Optical microscopy or fluorescence microscopy.}

Spore germination and fungal penetration were observed as described previously (Siah et al. 2010), with some modification. Inoculated leaves were decolorized in lactophenol-ethanol (lactic acid-phenol-ethanol, 1:1:1 [vol/vol/vol]) at $70^{\circ} \mathrm{C}$ for $20 \mathrm{~min}$, washed with DW, and fixed in chloral hydrate solution at $1 \mathrm{~g} / \mathrm{ml}$ for 2 days. Fungal growth was observed using a BX51 optical microscope (Olympus) under white light illumination. Images were taken with a DP70 camera and DP controller (version 2.2.1.227) software. For trypan blue staining, inoculated leaves were treated with $0.1 \%$ trypan blue in lactophenol-ethanol at $70^{\circ} \mathrm{C}$ for $20 \mathrm{~min}$ before being washed with chloral hydrate solution at $1.0 \mathrm{~g} / \mathrm{ml}$ to remove the remaining pigment. Images were captured as described above.

\section{Stomatal density analysis.}

Mature leaves were fixed in ethanol-acetic acid (9:1) for $4 \mathrm{~h}$, as described previously (Niwa et al. 2013). The samples were treated with chloral hydrate solution at $1.0 \mathrm{~g} / \mathrm{ml}$ for 2 or more days at $22^{\circ} \mathrm{C}$. Differential interference contrast images were captured with a BX51 optical microscope (Olympus). Averages and standard deviations of stomatal density for each sample were calculated from more than six leaves of six gentian plants.
The number of stomata in each leaf was counted from more than five images $\left(0.533 \mathrm{~mm}^{2} /\right.$ image $)$. For the statistical analysis shown in Figure $3 \mathrm{~B}$ and $\mathrm{C}$, multiple comparison analysis was performed using one-way analysis of variance and NewmanKeuls Multiple Comparison Test with PRISM5 software (GraphPad). Student's $t$ tests were performed with PRISM5 software for Figure 5B and C.

\section{Plasmid construction and recombinant proteins.}

RNA was isolated from 10-day-old $A$. thaliana plants using a Sepasol-RNA Super G kit (Nacalai) and cDNA was synthesized with ReverTra Ace (TOYOBO). The coding region of STOMAGEN was amplified by PCR using the primer set forward (5'-GGCCCTCGAGATGATAGGGTCGACAGCACC AACTTGTACGTAC- $\left.\bar{C}{ }^{\prime}\right)$ and reverse $\left(5^{\prime}\right.$-GGCCTCTAGATTAT CTATGACAAACACATCTATAATGA-3'). The resulting cDNA fragment was digested with $X h o I$ and $X b a I$ and subcloned into the corresponding sites of the pCold TF (Takara-Bio) vector.

pCold TF and pCold TF-STOMAGEN plasmids were transformed into Escherichia coli strain BL21. E. coli was cultured at $37^{\circ} \mathrm{C}$ with $110 \mathrm{rpm}$ shaking to reach a bacterial concentration of $0.8>$ optical density at $600 \mathrm{~nm}>0.4$. After the addition of $1 \mu \mathrm{M}$ isopropyl- $\beta$-D-thiogalactoside, cultures were incubated at $16^{\circ} \mathrm{C}$ for $20 \mathrm{~h}$ with $110 \mathrm{rpm}$ shaking to induce protein. Cultures were centrifuged at $5,000 \times g$ for $10 \mathrm{~min}$ and pellets were suspended with lysis solution $(1 \times$ phosphatebuffered saline [PBS], $\mathrm{pH} 7.4 ; \mathrm{NaCl}$ at $1.37 \mathrm{mmol} / \mathrm{liter}$; $\mathrm{Na}_{2} \mathrm{HPO}_{4}$ at $8.1 \mathrm{mmol} /$ liter; $\mathrm{KCl}$ at $2.68 \mathrm{mmol} / \mathrm{liter} ; \mathrm{KH}_{2} \mathrm{PO}_{4}$ at $1.47 \mathrm{mmol} /$ liter; lysozyme at $100 \mu \mathrm{g} / \mathrm{ml}$; and $10 \%$ Triton $\mathrm{X}$ 100). Suspended solutions were incubated with shaking at $4^{\circ} \mathrm{C}$ for $30 \mathrm{~min}$ and centrifuged at $11,000 \times \mathrm{g}$. Supernatants were mixed with TALON superflow (GE Healthcare) at $4^{\circ} \mathrm{C}$ for $10 \mathrm{~min}$ and washed with washing buffer (PBS and $5 \mathrm{mM}$ imidazole) three times. Peptides were eluted with elution buffer (1× PBS with $150 \mathrm{mM}$ imidazole) three times. Peptide solutions were filtered by syringe filter with a $0.45-\mu \mathrm{m}$ polyvinylidene diflouride membrane (GE Healthcare) and diluted in $1 \times$ PBS. Peptides obtained from the second or third elution solution were used for the STOMAGEN treatment assay.

\section{STOMAGEN peptide treatment.}

Shoot tips of gentian plants were transferred into control or EPFL9 peptide solution at $2 \mu \mathrm{g} / \mathrm{ml}$ for 2 days. Peptide-treated plants were grown on gentian growth media for 30 to 40 days. Newly developing leaves were used to count the number of stomata. To check susceptibility to $S g 20-35$, plants were transferred to $1.2 \%$ agar 30 to 40 days after peptide treatment and sprayed with $\mathrm{Sg} 20-35$ at a concentration of $5 \times 10^{5}$ spores/ml.

\section{ACKNOWLEDGMENTS}

We thank the Iwate Agricultural Research Center (IARC) and Hachimantai Floricultural Research and Development Center (HFRDC) for providing the gentian materials used in this study and helping with plant and fungal growth methods; and E. Tacken from Edanz Group for editing a draft of this article.

\section{LITERATURE CITED}

Abrash, E. B., and Bergmann, D. C. 2010. Regional specification of stomatal production by the putative ligand CHALLAH. Development 137:447-455

Ahuja, I., Kissen, R., and Bones, A. M. 2012. Phytoalexins in defense against pathogens. Trends Plant Sci. 17:73-90.

Arnaud, D., and Hwang, I. 2015. A sophisticated network of signaling pathways regulates stomatal defenses to bacterial pathogens. Mol. Plant 8:566-581. 
Carbone, I., and Kohn, L. M. 1999. A method for designing primer sets for speciation studies in filamentous ascomycetes. Mycologia 91:553-556.

Chinchilla, D., Zipfel, C., Robatzek, S., Kemmerling, B., Nürnberger, T., Jones, J. D., Felix, G., and Boller, T. 2007. A flagellin-induced complex of the receptor FLS2 and BAK1 initiates plant defence. Nature 448: 497-500.

Cohen, L., and Eyal, Z. 1993. The histology of processes associated with the infection of resistant and susceptible wheat cultivars with Septoria tritici. Plant Pathol. 42:737-743.

Dean, R., Van Kan, J. A. L., Pretorius, Z. A., Hammond-Kosack, K. E., Di Pietro, A., Spanu, P. D., Rudd, J. J., Dickman, M., Kahmann, R., Ellis, J., and Foster, G. D. 2012. The Top 10 fungal pathogens in molecular plant pathology. Mol. Plant Pathol. 13:414-430.

Duncan, K. E., and Howard, R. J. 2000. Cytological analysis of wheat infection by the leaf blotch pathogen Mycosphaerella graminicola. Mycol. Res. 104:1074-1082.

Fones, H., and Gurr, S. 2015. The impact of Septoria tritici blotch disease on wheat: An EU perspective. Fungal Genet. Biol. 79:3-7.

Fones, H. N., Steinberg, G., and Gurr, S. J. 2015. Measurement of virulence in Zymoseptoria tritici through low inoculum-density assays. Fungal Genet. Biol. 79:89-93.

Giraldo, M. C., and Valent, B. 2013. Filamentous plant pathogen effectors in action. Nat. Rev. Microbiol. 11:800-814.

Gómez-Gómez, L., and Boller, T. 2000. FLS2: An LRR receptor-like kinase involved in the perception of the bacterial elicitor flagellin in Arabidopsis. Mol. Cell 5:1003-1011.

Gudesblat, G. E., Torres, P. S., and Vojnov, A. A. 2009. Xanthomonas campestris overcomes Arabidopsis stomatal innate immunity through a DSF cell-to-cell signal-regulated virulence factor. Plant Physiol. 149: 1017-1027.

Han, S. K., and Torii, K. U. 2016. Lineage-specific stem cells, signals and asymmetries during stomatal development. Development 143: $1259-1270$

Hara, K., Kajita, R., Torii, K. U., Bergmann, D. C., and Kakimoto, T. 2007. The secretory peptide gene EPF1 enforces the stomatal one-cell-spacing rule. Genes Dev. 21:1720-1725.

Hara, K., Yokoo, T., Kajita, R., Onishi, T., Yahata, S., Peterson, K. M., Torii, K. U., and Kakimoto, T. 2009. Epidermal cell density is autoregulated via a secretory peptide, EPIDERMAL PATTERNING FACTOR 2 in Arabidopsis leaves. Plant Cell Physiol. 50:1019-1031.

Heichel, G. H., and Anagnostakis, S. L. 1978. Stomatal response to light of Solanum pennellii, Lycopersicon esculentum, and a graft-induced chimera. Plant Physiol. 62:387-390.

Hilu, H. B., and Bever, W. M. 1957. Inoculation, oversummering and suscept-pathogen relationships of Septoria tritici on Triticum species. Phytopathology 47:474-480.

Hosokawa, K., Matsuki, R., Oikawa, Y., and Yamamura, S. 2000. Production of transgenic gentian plants by particle bombardment of suspension-culture cells. Plant Cell Rep. 19:454-458.

Hunt, L., Bailey, K. J., and Gray, J. E. 2010. The signalling peptide EPFL9 is a positive regulator of stomatal development. New Phytol. 186: 609-614.

Hunt, L., and Gray, J. E. 2009. The signaling peptide EPF2 controls asymmetric cell divisions during stomatal development. Curr. Biol. 19: 864-869.

Jones, J. D. G., and Dangl, J. L. 2006. The plant immune system. Nature 444:323-329.

Jordá, L., Sopeña-Torres, S., Escudero, V., Nuñez-Corcuera, B., DelgadoCerezo, M., Torii, K. U., and Molina, A. 2016. ERECTA and BAK1 receptor like kinases interact to regulate immune responses in Arabidopsis. Front. Plant Sci. 7:897.

Kanzaki, H., Nirasawa, S., Saitoh, H., Ito, M., Nishihara, M., Terauchi, R., and Nakamura, I. 2002. Overexpression of the wasabi defensin gene confers enhanced resistance to blast fungus (Magnaporthe grisea) in transgenic rice. Theor. Appl. Genet. 105:809-814.

Katsir, L., Davies, K. A., Bergmann, D. C., and Laux, T. 2011. Peptide signaling in plant development. Curr. Biol. 21:R356-R364.

Kema, G. H. J., Yu, D. Z., Rijkenberg, F. H. J., Shaw, M. W., and Baayen, R. P. 1996. Histology of the pathogenesis of Mycosphaerella graminicola in wheat. Phytopathology 86:777-786.

Kondo, T., Kajita, R., Miyazaki, A., Hokoyama, M., Nakamura-Miura, T., Mizuno, S., Masuda, Y., Irie, K., Tanaka, Y., Takada, S., Kakimoto, T., and Sakagami, Y. 2010. Stomatal density is controlled by a mesophyllderived signaling molecule. Plant Cell Physiol. 51:1-8.

Liu, J., Elmore, J. M., Fuglsang, A. T., Palmgren, M. G., Staskawicz, B. J., and Coaker, G. 2009. RIN4 functions with plasma membrane $\mathrm{H}+$-ATPases to regulate stomatal apertures during pathogen attack. PLoS Biol. 7:e1000139.
Macho, A. P., and Zipfel, C. 2014. Plant PRRs and the activation of innate immune signaling. Mol. Cell 54:263-272.

Marshall, E., Costa, L. M., and Gutierrez-Marcos, J. 2011. Cysteine-rich peptides (CRPs) mediate diverse aspects of cell-cell communication in plant reproduction and development. J. Exp. Bot. 62:1677-1686.

Martin-Hernandez, A. M., Dufresne, M., Hugouvieux, V., Melton, R., and Osbourn, A. 2000. Effects of targeted replacement of the tomatinase gene on the interaction of Septoria lycopersici with tomato plants. Mol. Plant-Microbe Interact 13:1301-1311.

Melotto, M., Underwood, W., Koczan, J., Nomura, K., and He, S. Y. 2006. Plant stomata function in innate immunity against bacterial invasion. Cell 126:969-980.

Meng, X., Chen, X., Mang, H., Liu, C., Yu, X., Gao, X., Torii, K. U., He, P., and Shan, L. 2015. Differential function of Arabidopsis SERK family receptor-like kinases in stomatal patterning. Curr. Biol. 25:2361-2372.

Miedes, E., Vanholme, R., Boerjan, W., and Molina, A. 2014. The role of the secondary cell wall in plant resistance to pathogens. Front. Plant Sci. $5: 358$.

Miller, P. M. 1955. V-8 juice agar as a general purpose medium for fungi and bacteria. Phytopathology 45:461-462.

Miya, A., Albert, P., Shinya, T., Desaki, Y., Ichimura, K., Shirasu, K., Narusaka, Y., Kawakami, N., Kaku, H., and Shibuya, N. 2007. CERK1, a LysM receptor kinase, is essential for chitin elicitor signaling in Arabidopsis. Proc. Natl. Acad. Sci. U.S.A. 104:19613-19618.

Moerschbacher, B., and Mendgen, K. 2000. Structural aspects of defense. Pages 231-277 in: Mechanisms of Resistance to Plant Diseases. A. J. Slusarenko, R. S. S. Fraser, and L. C. van Loon, eds. Springer Science and Business Media

Murashige, T., and Skoog, F. 1962. A revised medium for rapid growth and bioassays with tobacco tissue cultures. Physiol. Plant. 15:473-497.

Nekoduka, S., Horaguchi, H., Akasaka, S., Chiba, K., Hikage, T., Kawamura, H., Nakatsuka, T., and Nishihara, M. 2013. Inheritance of resistance to brown leaf spot disease in gentians. J. Gen. Plant Pathol. 79:165-167.

Nishihara, M., Tasaki, K., Sasaki, N., and Takahashi, H. 2018. Development of basic technologies for improvement of breeding and cultivation of Japanese gentian. Breed. Sci. 68:14-24.

Niwa, T., Kondo, T., Nishizawa, M., Kajita, R., Kakimoto, T., and Ishiguro, S. 2013. EPIDERMAL PATTERNING FACTOR LIKE5 peptide represses stomatal development by inhibiting meristemoid maintenance in Arabidopsis thaliana. Biosci. Biotechnol. Biochem. 77:1287-1295.

Niyo, K. A., McNabb, H. S., Jr., and Tiffany, L. H. 1986. Ultrastructure of the ascocarps, asci, and ascospores of Mycosphaerella populorum. Mycologia 78:202-212.

O’Donnell, K., and Cigelnik, E. 1997. Two divergent intragenomic rDNA ITS2 types within a monophyletic lineage of the fungus Fusarium are nonorthologous. Mol. Phylogenet. Evol. 7:103-116.

O’Donnell, K., Kistler, H. C., Cigelnik, E., and Ploetz, R. C. 1998. Multiple evolutionary origins of the fungus causing Panama disease of banana: Concordant evidence from nuclear and mitochondrial gene genealogies. Proc. Natl. Acad. Sci. U.S.A. 95:2044-2049.

Ohno, Y., Tsunemi, J., Ishikawa, S., and Yamazaki, S. 1996. Ecology and pathogen of gentian leaf blight. Proc. Kanto-Tosan Plant Prot. Soc. 43: 117-119.

Petutschnig, E. K., Jones, A. M. E., Serazetdinova, L., Lipka, U., and Lipka, V. 2010. The lysin motif receptor-like kinase (LysM-RLK) CERK1 is a major chitin-binding protein in Arabidopsis thaliana and subject to chitin-induced phosphorylation. J. Biol. Chem. 285:28902-28911.

Quaedvlieg, W., Groenewald, J. Z., de Jesús Yáñez-Morales, M., and Crous, P. W. 2012. DNA barcoding of Mycosphaerella species of quarantine importance to Europe. Persoonia 29:101-115.

Saccardo, P. A. 1884. Sylloge Fungorum: Sylloge Sphaeropsidearum et Melanconiearum. Sylloge Fungorum. 3:1-840.

Saito, I., and Kaji, K. 2006. Ciborinia gentianae sp. nov., the causal organism of sclerotial flower blight of cut-flower gentians. Mycoscience 47:41-47.

Schoina, C., and Govers, F. 2015. The oomycete phytophthora infestans, the irish potato famine pathogen. Pages 371-378 in: Principles of PlantMicrobe Interactions. B. Lugtenberg, ed. Springer, Cham, Switzerland.

Schwessinger, B., Roux, M., Kadota, Y., Ntoukakis, V., Sklenar, J., Jones, A., and Zipfel, C. 2011. Phosphorylation-dependent differential regulation of plant growth, cell death, and innate immunity by the regulatory receptor-like kinase BAK1. PLoS Genet. 7:e1002046.

Shipton, W. A., Boyd, S. R. J., Rosielle, A. A., and Shearer, B. I. 1971. Common Septoria diseases of wheat. Bot. Rev. 37:231-262.

Siah, A., Deweer, C., Duyme, F., Sanssené, J., Durand, R., Halama, P., and Reignault, P. 2010. Correlation of in planta endo-beta-1,4-xylanase activity with the necrotrophic phase of the hemibiotrophic fungus Mycosphaerella graminicola. Plant Pathol. 59:661-670. 
Steinberg, G. 2015. Cell biology of Zymoseptoria tritici: Pathogen cell organization and wheat infection. Fungal Genet. Biol. 79:17-23.

Stevenson, W. R. 1991. Septoria leaf spot. Page 22 in: Compendium of Tomato Diseases. J. B. Jones, R. E. Stall, and T. A. Zitter, eds. American Phytopathological Society, St. Paul, MN.

Stintzi, A., Heitz, T., Prasad, V., Wiedemann-Merdinoglu, S., Kauffmann, S., Geoffroy, P., Legrand, M., and Fritig, B. 1993. Plant 'pathogenesis-related' proteins and their role in defense against pathogens. Biochimie 75:687-706.

Stukenbrock, E. H., Quaedvlieg, W., Javan-Nikhah, M., Zala, M., Crous, P. W., and McDonald, B. A. 2012. Zymoseptoria ardabiliae and Z. pseudotritici, two progenitor species of the septoria tritici leaf blotch fungus Z. tritici (synonym: Mycosphaerella graminicola). Mycologia 104:1397-1407.

Su, J., Zhang, M., Zhang, L., Sun, T., Liu, Y., Lukowitz, W., Xu, J., and Zhang, S. 2017. Regulation of stomatal immunity by interdependent functions of a pathogen-responsive MPK3/MPK6 cascade and abscisic acid. Plant Cell 29:526-542.

Sugano, S. S., Shimada, T., Imai, Y., Okawa, K., Tamai, A., Mori, M., and Hara-Nishimura, I. 2010. Stomagen positively regulates stomatal density in Arabidopsis. Nature 463:241-244.

Takata, N., Yokota, K., Ohki, S., Mori, M., Taniguchi, T., and Kurita, M. 2013. Evolutionary relationship and structural characterization of the EPF/EPFL gene family. PLoS One 8:e65183.

Underwood, W. 2012. The plant cell wall: A dynamic barrier against pathogen invasion. Front. Plant Sci. 3:85.

Van Ginkel, M., and Rajaram, S. 1993. Breeding for durable resistance to diseases in wheat: An international perspective. Pages 259-272 in: Durability of Disease Resistance. T. Jacobs and J. E. Parlevliet, eds. Kluwer Academic, Dordrecht, The Netherlands.

Verkley, G. J. M., Quaedvlieg, W., Shin, H. D., and Crous, P. W. 2013. A new approach to species delimitation in Septoria. Stud. Mycol. 75:213-305.
Wang, H., Ngwenyama, N., Liu, Y., Walker, J. C., and Zhang, S. 2007. Stomatal development and patterning are regulated by environmentally responsive mitogen-activated protein kinases in Arabidopsis. Plant Cell 19:63-73.

White, T. J., Bruns, T., Lee, S., and Taylor, J. 1990. Amplification and direct sequencing of fungal ribosomal RNA genes for phylogenetics. Pages 315-322 in: PCR Protocols: A Guide to Methods and Applications. M. Innis, D. Gelfand, J. Sninsky, T. White, eds. Academic Press, Cambridge, MA, U.S.A.

Willmann, R., Lajunen, H. M., Erbs, G., Newman, M. A., Kolb, D., Tsuda, K., Katagiri, F., Fliegmann, J., Bono, J. J., Cullimore, J. V., Jehle, A. K. Götz, F., Kulik, A., Molinaro, A., Lipka, V., Gust, A. A., and Nürnberger, T. 2011. Arabidopsis lysin-motif proteins LYM1 LYM3 CERK1 mediate bacterial peptidoglycan sensing and immunity to bacterial infection. Proc. Natl. Acad. Sci. U.S.A. 108:19824-19829.

Yoshiike, T. 1992. Foundation of cultivation. Pages 68-72 in: Breeding and Cultivation of Gentian. T. Yoshiike, ed. Seibundoshinkosha.

Zhang, Y. J., Zhang, S., Liu, X. Z., Wen, H. A., and Wang, M. 2010. A simple method of genomic DNA extraction suitable for analysis of bulk fungal strains. Lett. Appl. Microbiol. 51:114-118.

Zipfel, C., Kunze, G., Chinchilla, D., Caniard, A., Jones, J. D. G., Boller, T., and Felix, G. 2006. Perception of the bacterial PAMP EF-Tu by the receptor EFR restricts Agrobacterium-mediated transformation. Cell 125:749-760.

Zoulias, N., Harrison, E. L., Casson, S. A., and Gray, J. E. 2018. Molecular control of stomatal development. Biochem. J. 475:441-454.

AUTHOR-RECOMMENDED INTERNET RESOURCE

Edanz Group; https://www.edanzediting.com/ac 